\title{
STUDI PEMANFAATAN HUMA BETANG TUMBANG ANOI SEBAGAI SUMBER PEMBELAJARAN SEJARAH LOKAL DI KALIMANTAN TENGAH
}

\author{
Study on The Utilization of Betang Tumbang Anoi as \\ a Source of Lokal History Learning in Central Kalimantan
}

\author{
Kristanto V Baddak ${ }^{1 *}$ \\ Yulia Yustha ${ }^{2}$ \\ Manya $^{3}$
}

IFKIP Universitas PGRI Palangka

Raya

2,3Fakultas Pertanian Universitas

PGRI Palangka Raya

*email:

kristiantovbaddak@gmail.com

\begin{abstract}
Abstrak
Suatu penelitian kualitatif telah dilaksanakan untuk mengetahui peranan Betang Tumbang Anoi sebagai sumber pembelajaran sejarah lokal di Provinsi Kalimantan Tengah. Penelitian dilakukan di Kota Palangka Raya dan Kabupaten Gunung Mas dengan responden berasal dari guru sejarah SMA di kedua daerah tersebut. Hasil penelitian menunjukkan bahwa Materi sejarah lokal sangat penting dan meskipun tidak secara eksplisit ada dalam kurikulum K 13, namun dapat diberikan. Materi sejarah lokal tidak bertentangan dengan kurikulum $\mathrm{K} / 3$ bahkan menjadi bagian dari Kurikulum K 13. Sejarah lokal penting diajarkan agar generasi muda lebih mengenal identitasnya dan meningkatkan rasa kebangsaan melalui tokoh-tokoh lokal yang lebih membumi. Pembelajaran sejarah lokal juga membawa perubahan positif pada diri siswa dengan mengenalkan sejarah lokal antara lain tumbuhnya nasionalisme dan kesadaran sejarah. Betang Tumbang Anoi sebagai tempat pertemuan damai Tumbang Anoi dapat dijadikan sebagai sumber pembelajaran sejarah lokal Provinsi Kalimantan Tengah, namun pemanfaatannya secara langsung menghadapi kendala berupa letak geografis yang jauh, prasarana transportasi yang berat dan biaya perjalanan yang mahal. Pemanfaatan Betang Tumbang Anoi sebagai sumber pembelajaran sejarah lokal menggunakan alat bantu berupa gambar atau foto yang diperoleh melalui internet yang terbukti mampu meningkatkan tingkat pemahaman siswa.
\end{abstract}

\section{Accepted}

September 2019

Published

Desember 2019

\begin{abstract}
A qualitative study has been carried out to determine the role of Betang Tumbang Anoi as a source of local history learning in Central Kalimantan Province. The study was conducted in Palangka Raya City and Gunung Mas Regency with respondents coming from high school history teachers in both regions. The results show that local history material is very important and although it is not explicitly contained in the $\mathrm{K} / 3$ curriculum, it can be given. Local history material does not conflict with the $\mathrm{K} / 3$ curriculum and even becomes part of $K$ curriculum 13. Local history is important to be taught so that the younger generation is more familiar with their identities and increases their sense of nationality through local characters who are more down to earth. Learning local history also brings positive changes in students by introducing local history, among others, the growth of nationalism and historical awareness. Betang Tumbang Anoi as a peaceful meeting place Tumbang Anoi can be used as a source of local history learning in Central Kalimantan Province, but its use directly faces obstacles in the form of remote geographical location, poor transportation infrastructure and expensive travel costs. The use of Betoi Tumbang Anoi as a source of local history learning uses tools in the form of pictures or photographs obtained through the internet which are proven to be able to increase students' level of understanding.
\end{abstract}




\section{PENDAHULUAN}

Pembelajaran sejarah secara umum dinilai dan dianggap oleh siswa tidak terlalu penting. Karena guru sejarah hanya menekankan kepada siswa untuk menghafal suatu informasi masa lalu seperti siapa, kapan, dan dimana peristiwa itu terjadi, tanpa melakukan rancangan pembelajaran sejarah yang lebih mengarah untuk menganalisis suatu informasi masa lalu tersebut (Sayono, 2013). Proses pendidikan khususnya pengajaran sejarah, ibarat mengajak peserta didik menengok ke belakang dengan tujuan melihat ke depan. Dapat disimpulkan bahwa dengan mempelajari nilai-nilai kehidupan masyarakat di masa lampau, diharapkan siswa atau peserta didik mencari atau mengadakan seleksi terhadap nilai-nilai kompleks di masa kini maupun yang akan datang (Sirnayatin, 2017). Maka dari itu, guru sejarah harus mempunyai wawasan yang luas serta mendalam dan mempunyai motivasi yang tinggi dalam proses pembelajaran sejarah sehingga makna yang terkandung dalam mata pelajaran sejarah dapat tersampaikan. Guru sejarah mempunyai peran yang penting dalam pengembangan karakter siswa sebagaimana yang tertuang dalam Peraturan Menteri Pendidikan No.16 Tahun 2007 tentang Standar Kualifikasi dan Kompetensi
Guru menyatakan bahwa “...guru sejarah harus menguasai struktur keilmuan, ruang lingkup, dan objek sejarah; membedakan pendekatan-pendekatan sejarah; menguasai materi sejarah yang luas dan mendalam serta menunjukkan manfaat mata pelajaran sejarah". Selain itu, guru sejarah harus membantu dalam proses internalisasi nilainilai positif di dalam diri siswa yang tidak bisa digantikan oleh media pendidikan secanggih apapun (Tukidi, 20I I)

Kenyataan pembelajaran sejarah di Sekolah Menengah Atas (SMA) yang ada di Kalimantan Tengah, sudah berjalan dengan baik dan efektif sesuai dengan tujuan pembelajaran sejarah yang ingin dicapai yaitu untuk mencerdaskan dan membentuk karakter bangsa serta memberikan nilai-nilai moral terhadap generasi masa kini. Apalagi jika menggunakan data normatif bahwa setiap kali kenaikan kelas hampir semua siswa dapat melampaui nilai KKM (Kriteria Ketuntasan Minimal), walaupun sangat diyakini bahwa nilai KKM bukan jaminan gambaran kemampuan yang sesungguhnya (Sayono, 2017).

Namun masih ada kekurangannya, yakni keengganan guru sejarah menggunakan sumber-sumber sejarah lokal dalam pembelajaran sejarah. Kondisi ini juga didukung oleh kurangnya kreatifitas guru 
untuk memanfaatkan sumber sejarah lokal di Provinsi Kalimantan Tengah yang tersedia banyak untuk di pakai dan dipelajari. Padahal penerapan sejarah lokal juga membawa perubahan positif pada diri siswa dengan mengenalkan sejarah lokal antara lain tumbuhnya nasionalisme, kesadaran sejarah, berpikir kritis, gotong royong, dan sebagainya (Wijayanti, 2017). Dengan berlakunya Kurikulum 2013, maka penggunaan sejarah lokal mempunyai ruang yang besar untuk diimplementasikan.

Penelitian ini bertujuan untuk mengetahui penggunaan dan kedudukan Betang Tumbang Anoi - sebagai salah satu situs sejarah terpenting di Provinsi Kalimantan Tengah sebagai sumber sejarah lokal di Provinsi Kalimantan Tengah.

\section{METODE PENELITIAN}

Metodologi penelitian yang digunakan adalah penelitian kualitatif dengan pendekatan deskritif analisis. Metode deskriptif adalah suatu metode dalam meneliti status sekelompok manusia, suatu objek, suatu set kondisi, suatu sistem pemikiran ataupun suatu klas peristiwa. Tujuan dari penelitian deskriptif adalah untuk membuat deskripsi, gambaran, lukisan secara sistematis, faktual dan akurat mengenai faktafakta, sifat-sifat serta hubungan antara berbagai fenomena yang diteliti (Nazir, 2003).

Penelitian ini akan menggunakan data primer dan data sekunder. Data primer diperoleh melalui wawancara, observasi atau pengamatan langsung, dan dokumentasi. Wawancara dilakukan dengan informan atau narasumber yang terkait dengan tema penelitian ini terdiri dari guru sejarah SMA Kota Palangka Raya dan Kabupaten Gunung Mas. Guru Sekolah SMA di Kota Palangka Raya dan Kabupaten Gunung Mas di pilih karena lokasinya yang paling dekat dengan Betang Tumbang Anoi. Dokumentasi yang dipergunakan dalam penelitian berupa pengambilan foto-foto, rekaman, catatan dan lain-lain.

Validitas data dilakukan dengan teknik triangulasi sumber, Triangulasi sumber yang dilakukan dalam penelitian ini adalah dengan membandingkan hasil pengamatan dengan hasil wawancara, kemudian membandingkan hasil wawancara dengan dokumen yang terkait dengan tema penelitian, sehingga dengan mengunakan triangulasi sumber ini akan mengarahkan peneliti dalam mengumpulkan data wajib untuk mengunakan beragam sumber data yang tersedia. Adapun data sekunder diperoleh dari pengelola Rumah Betang, instansi teknis terkait seperti Dinas Pariwisata Provinsi Kalimantan Tengah ataupun sumber pendukung penting lainnya.

Setelah data dikumpulkan, selanjutnya dilakukan analisis. Analisis data merupakan proses penyusunan data yang berarti pengelompokan data dalam pola, tema dan kategori sehingga mudah untuk dibaca dan dipahami (Nazir, 2003). Berkenaan dengan 
analisis data dalam penelitian kualitatif, Huberman dan Miles dalam Nazir (2003) mengajukan model analisis data yang disebut “analisis interaktif” yang terdiri dari 3 komponen, yaitu reduksi data, penyajian data dan penarikan kesimpulan. Ketiga komponen tersebut ditambah dengan pengumpulan data merupakan kegiatan yang jalin menjalin selama masa penelitian. Proses analisis interaktif ini merupakan proses siklus dimana peneliti harus siap untuk terus bergerak di antara keempat sumbu yaitu pengumpulan data, reduksi data, penyajian data dan penarikan kesimpulan.

\section{HASIL PENELITIAN}

Berdasarkan hasil wawancara dan penelusuran dokumen selama penelitian, telah diperoleh beberapa fakta yang diuraikan sebagai berikut.

\section{Pengajaran Sejarah Lokal}

Berdasarkan wawancara dengan $M$.

Noor (Guru Sejarah SMAN 5 Palangka

Raya) diketahui bahwa materi sejarah

lokal tidak ada dalam kurikulum K I3 revisi tahun 2018 :

"Kurikulum yang dipergunakan sekarang adalah Kurikulum K.I3 Revisi 2018, dimana tidak ada materi sejarah lokal. Bagi seluruh siswa diberikan materi sejarah nasional, sementara bagi siswa jurusan IPS disamping diberikan materi sejarah nasional juga diberikan materi peminatan sejarah yang berisi sejarah dunia"

Namun narasumber lain menyatakan bahwa meskipun materi sejarah lokal tidak ada dalam kurikulum $\mathrm{K}$ I3, namun sebenarnya dapat diberikan kepada siswa, bahkan telah ada kesepakatan di antara anggota Asosiasi Guru Sejarah Indonesia (AGSI) dan Musyawarah Guru Mata Pelajaran (MGMP) Sejarah untuk memberikan materi sejarah lokal. Yusnarti Novelianty (Guru Sejarah SMAN I Palangka Raya/Pengurus Asosiasi Guru Sejarah Indonesia/AGSI Kalimantan Tengah) mengatakan :

"Materi sejarah lokal memang tidak ada dalam kurikulum K.I3, tetapi semua guru sejarah menyisipkan sendiri oleh guru yang bersangkutan. Responden sebagai Pengurus/Anggota AGSI menyatakan bahwa dalam Simposium AGSI di Palembang sudah ada kesepakatan untuk memasukkan materi sejarah lokal, tinggal Musyawarah Guru Mata Pelajaran (MGMP) saja yang bergerak"

Sementara itu, Sintara TT. Asang (Guru Sejarah SMAN 2 Palangka Raya/Ketua Komunitas Sejarah dan Budaya Kalimantan Tengah) mengatakan :

"Memang benar bahwa materi sejarah lokal tidak ada dalam Kurikulum K.I3 namun guru diperbolehkan berimprovasi dengan materi pelajaran. Peranan guru dalam memperkenalkan sejarah lokal 
sangat besar. Di SMAN 2 Palangka Raya, untuk peminatan sejarah sudah dimasukkan materi penelitian sejarah sejak Kelas $X$ dimana focus materi ini adalah sejarah lokal. Ini atas inisiatif saya sendiri dan disepakati oleh guru-guru sejarah yang lain lalu disetujui Kepala Sekolah"

Endang Hartati (Guru Sejarah SMAN 4 Palangka Raya/Anggota AGSI

Kalimantan Tengah) menambahkan :

“Materi sejarah lokal tidak diberikan tersendiri, tetapi terintegrasi dalam materi yang ada. Bukan hanya siswa Jurusan IPS yang memperoleh pelajaran peminatan sejarah, tetapi juga siswa jurusan IPA yang memperoleh materi sejarah nasional. Materi sejarah lokal ini sangat penting bagi siswa, jadi perlu disampaikan supaya siswa tahu peristiwa-peristiwa yang terjadi di Kalimantan Tengah pada masa lampau"

Riswinae (Guru SMAN Tewah Kabupaten Gunung Mas) juga mengatakan :

"Sejarah lokal sering disinggung pada saat menyampaikan materi sejarah dunia, misalnya saat membahas perdamaian dunia juga menyinggung tentang pertemuan damai Tumbang Anoi yang mempersatukan suku-suku Dayak di Kalimantan (tidak hanya di Kaliamntan Tengah). Jadi meskipun dalam silabus tidak ada, guru dapat mencari cara untuk menyampaikan sejarah lokal karena sejarah lokal itu penting"
Guru Sejarah SMA Negeri Kuala Kurun yaitu Kanety, Santy dan Emy Oktaviamerry memberikan penjelasan yang mirip,

Memang pada dasarnya materi sejarah lokal tidak ada dalam silabus pada Kurikulum K.I3, namun sesuai dengan Musyawarah Guru Mata Pelajaran (MGMP) sejarah serta arahan dari Dinas Pendidikan, materi ini tetap diberikan. Tidak harus diberikan secara khusus, bisa juga dilakukan bersamaan dengan materi yang lain. Misalnya ketika membahas perjuangan mempertahankan kemerdekaan (materi sejarah nasional) pada saat itu juga disampaikan cerita tentang Bapak Tjilik Riwut, Pahlawan Nasional dari Kalimantan Tengah.

Berdasarkan keterangan seluruh narasumber ditemukan fakta bahwa materi sejarah lokal sangat penting dan meskipun tidak secara eksplisit ada dalam kurikulum K I3, namun dapat diberikan. Materi sejarah lokal tidak bertentangan dengan kurikulum $\mathrm{K}$ I3 bahkan menjadi bagian dari Kurikulum K I3.

\section{Metode Pengajaran Sejarah Lokal}

Seluruh responden menyatakan bahwa pengajaran sejarah lokal dilakukan dengan lawatan sejarah untuk melihat langsung situs sejarah lokal. Interaksi dengan obyek sejarah yang bisa 
langsung dilihat membuat materi pelajaran sejarah dapat lebih mudah diingat, dipahami dan disebarkan melalui media sosial. Yusnarti

Novelianty berpendapat:

"Lawatan sejarah dengan mengajak siswa mengunjungi objek sejarah berdampak positif bagi siswa, karena suasananya rekreasi dan siswa tidak tegang sehingga pelajaran lebih mudah diterima. Apalagi siswa sambil selfie (swafoto). Obyek yang paling erring dikunjungi adalah Museum Balanga di Kota Palangka Raya.”

\section{Sintara TT Asang mengatakan :}

"Selama ini sejarah identik dengan hafalan dan buku-buku tebal sehingga cenderung membosankan setelah melihat langsung obyek sejarah, siswa lebih cepat paham dan tidak lupa. Dengan melihat langsung, majinasi siswa juga lebih hidup dan dapat membayangkan peristiwa yang sebenarnya. Selama ini sejarah identik dengan hafalan dan bukubuku tebal sehingga cenderung membosankan setelah melihat langsung obyek sejarah, siswa lebih cepat paham dan tidak lupa. Dengan melihat langsung, majinasi siswa juga lebih hidup dan dapat membayangkan peristiwa yang sebenarnya."

Endang Hartati mempunyai pendapat yang serupa, :

"Ketika mengikuti lawatan sejarah siswa sangat antusias dalam mempelajari benda-benda bersejarah di dalamnya. Beberapa siswa yang berasal dari suku Dayak ada yang sudah tahu namun ada juga yang belum tahu, sedang siswa yang berasal dari suku lain banyak yang tidak tahu. Mereka saling berdiskusi dan memberikan penjelasan, satu sama lain. Tambahan lagi, para siswa bisa berfoto dan di upload di media social (IG, FB dan tweeter). Secara tidak langsung, mereka juga ikut menyebarluaskan pengetahuan tentang sejarah lokal khususnya di lingkungannya."

\section{Pertemuan Tumbang Anoi}

Betang Tumbang Anoi mempunyai peran besar dalam sejarah lokal Provinsi Kalimantan Tengah, bahkan seluruh Kalimantan. Di tempat ini berlangsung Kerapatan Besar Adat (Rapat Damai) Tumbang Anai pada tanggal 22 Mei s/d 24 Juli 1894. Bertindak sebagai tuan rumah adalah Damang Batu serta melibatkan semua anak suku Dayak di seluruh Kalimantan yang selama berabad-abad saling berperang. Hal ini dikatakan oleh Gauri Rampai berikut:

Meskipun ada beberapa versi dan ada beberapa perbedaan dalam detail pertemuan Tumbang Anoi, tetapi dampak pertemuan Tumbang Anoi sangat besar dan dapat dirasakan sampai sekarang. Dampak terbesar pertemuan Tumbang Anoi adalah perdamaian. Bisa dibayangkan bagaimana mencekam kehidupan suku Dayak pada waktu itu karena adanya tradisi kayau (perembahan untuk acara tiwah), 
jipen (penangkapan untuk dijadikan budak) dan balas dendam antar sub suku. Praktis mereka hanya hidup di lingkungan betang saja, seandainya keluar dari lingkungan betang akan dilakukan bersama-sama dan dengan persiapan yang baik (persenjataan, jumlah orang, tanda bahaya dan sebagainya). Setelah pertemuan Tumbang Anoi, suasana berubah total, orang-orang sudah berani bepergian keluar betang bahkan pergi ke tempat-tempat jauh tanpa rasa takut.

Perrtemuan Tumbang Anoi juga membuktikan bahwa suku Dayak merupakan entitas yang mau belajar dan sudah belajar. Bisa jadi prakarsa pertemuan Tumbang Anoi berasal dari Pemerintah Belanda, tetapi tanpa dukungan tokoh-tokoh Dayak tentu tidak akan sukses. Fakta ini membuktikan bahwa para tokoh (bersama masyarakatnya) tersebut sudah melihat (dan belajar tentang) dampak dari situasi pada saat itu serta "mau berubah" untuk kelangsungan hidup anak cucunya. Kesadaran untuk merubah ini merupakan hasil proses belajar internal di kalangan suku Dayak. Dampak lain adalah perdagangan. Diantara delegasi yang hadir sebagian adalah pedagang, sehingga motif ekonomi (perdagangan) sangat jelas terbayang dalam pertemuan Tumbang Anoi tersebut.

\section{Mimi (Guru Sejarah SMA PGRI 2}

Palangka Raya mengatakan :

Tidak ada guru sejarah di Kalimantan Tengah yang belum tahu peristiwa Tumbang Anoi (Rapat/Pertemuan Tumbang Anoi Pen) karena peristiwa itu merupakan peristiwa yang sangat penting bagi suku Dayak di Kalimantan.

Sementara itu, Sinthara TT Asang mendukung pendapat Gauri Rampai, dia mengatakan

Pertemuan bersejarah itu dapat dilihat dari berbagai segi, yaitu (I) Lahirnya hokum adat, karena sejak pertemuan tersebut disepakati berbagai ketentuan yang mengatur hubungan antar suku, antar kampong, antar betang yang ada di Kalimantan pada saat itu; (2) pembentukan struktur pemerintahan suku Dayak di Kalimantan, sejak saat itu struktur pemerintahan di atur lebih baik, siapa bertugas apa dan bagaimana di atur; (3) Mendorong peningkatan pendidikan, sebelum ada pertemuan, pada saat musim tiwah anak-anak tidak berani keluar rumah sehingga tidak bisa belajar. Setelah pertemuan Tumbang Anoi, banyak anak-anak yang berani meninggalkan betangnya pergi ke daerah-daerah yang jauh untuk menuntut ilmu; (4) perekonomian maju, karena setelah perdamaian tercipta, masyarakat berani mencari ikan, berburu atau bertanam ke tempat yang lebih jauh sehingga hasilnya lebih banyak dan para pedagang dari luar suku/kampong/betang bisa datang untuk membeli hasil-hasil pertanian

Keterangan dari narasumber yang lain mendukung pendapat Mimi bahwa tidak ada guru sejarah di Provinsi Kalimantan Tengah yang tidak mengetahui peristiwa besar di Betang Tumbang Anoi pada 
tahun 1894. Peristiwa ini bahkan dikenal oleh para sejarawan luar daerah dan asing, hal ini terlihat dari I) Foto dokumentasi di Betang Tumbang Anoi melibatkan orang asing (Eropa) dan beberapa di antaranya diperoleh dari museum di Negeri Belanda; dan (2) Para tamu yang mengunjungi Betang Tumbang Anoi sebagian besar berasal dari luar daerah dan luar negeri (mayoritas dari Belanda dan Jerman).

\section{Betang Tumbang Anoi sebagai}

\section{Sumber Pembelajaran Sejarah}

\section{Lokal}

Betang Tumbang Anoi sebagai situs bersejarah merupakan sumber pembelajaran sejarah lokal yang sangat tepat. Beberapa responden menyatakan hal yang sama. Yusnarti Novelianty mengatakan, "Sejarah Tumbang Anoi sangat pas untuk dijadikan materi sejarah lokal karena sangat penting bagi suku Dayak”. Sintara TT. Asang juga mengatakan :

"Pertemuan Tumbang Anoi sangat bersejarah, selama 3 bulan semua suku yang terlibat peperangan dan pertikaian didamaikan satu per satu". Narasumber lain, Gauri Rampai berpendapat bahwa, "dampak pertemuan Tumbang Anoi sangat besar dan dapat dirasakan sampai sekarang."
Berdasarkan pengamatan langsung, pada Betang Tumbang Anoi terdapat berbagai foto dokumentasi pertemuan Tumbang Anoi tahun 1894 yang menggambarkan situasi persitiwa bersejarah tersebut (Gambar I)
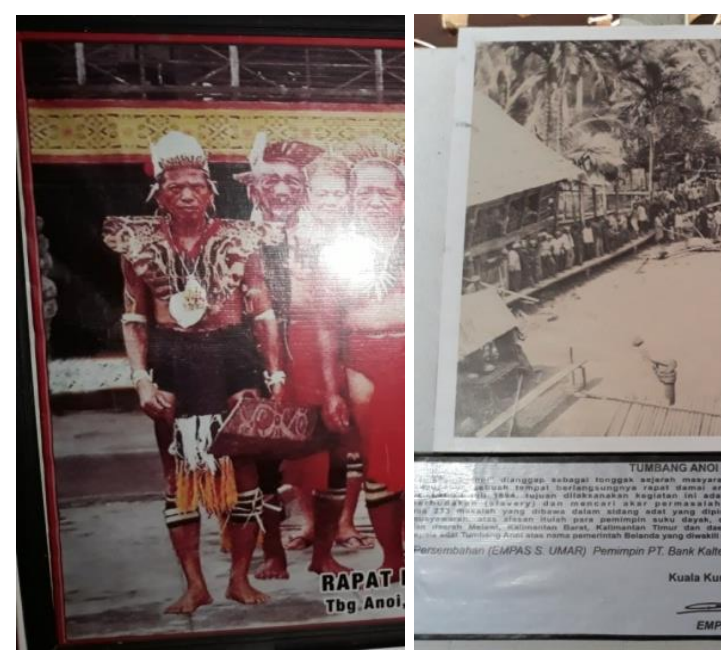

Gambar I

Dokumentasi Rapat/Pertemuan

Tumbang Anoi 1894

(Sumber : Dokumentasi Peneliti)

Meskipun Betang Tumbang Anoi merupakan sumber sejarah lokal yang penting, namun hanya dua narasumber yang pernah mengunjungi situs bersejarah tersebut, yaitu Gauri Rampai dan Riswinae (Guru Sejarah SMA Negeri Tewah). Medan berat dan jarak yang jauh menjadi sebab kenapa situs ini jarang dikunjungi. Gauri Rampai mengatakan,

“Lokasi Betang Tumbang Anoi yang jauh memang menjadi 
kendala, tetapi ketika kita mempelajari sejatah lokal sebaiknya tidak terpusat pada bentuk fisik (ditemukannya bukti fisik, atau dilihatnya bukti fisik) tetapi pada "nilai dan system social" dibalik bentuk fisik itu"

\section{Mimi (Guru Sejarah SMA PGRI}

Palangka Raya mengatakan,

"Saya sendiri belum pernah berkunjung ke Betang Tumbang Anoi karena jauh. Waktu perjalanan bisa memakan waktu 3 hari PP. Siswa pun belum pernah diajak ke Betang Tumbang Anoi karena alasan waktu dan biaya. Meskipun belum pernah mengunjungi situs Tumbang Anoi, sejarah pertemuan Tumbang Anoi tetap diberikan kepada siswa, termasuk menunjukkan foto dan gambar, khususnya foto Damang Batu sebagai tuan rumah (pengurus) betang Tumbang Anoi pada waktu itu. Karena fasilitas sekolah yang terbatas, saya hanya bisa menunjukkan gambar/foto/film dari smartphone yang saya miliki"

Yusnarti Novelianty mengatakan :

"Dalam rangka mendekatkan siswa dengan materi sejarah lokal, saya memperlihatkan gambargambar Betang Tumbang Anoi yang diperoleh dari internet atau memberikan tugas kepada siswa untuk mencari gambar/foto Betang Tumbang Anoi. Karena Betang Tumbang Anoi sangat jauh. Biaya perjalanannya mahal, sekitar Rp. I juta per orang"
Guru-guru Sejarah dari SMA Negeri Kurun yang lebih dekat juga belum pernah pergi ke Betang Tumbang Anoi, “Diskusi tentang sejarah lokal. Pemberian materi dilakukan dengan gambar dan foto, terkadang gambar dan foto ditunjukkan lewat hp guru kalau sarana pembelajaran tidak mendukung. Namun sampai sekarang belum pernah pergi ke Betang Tumbang Anoi. Kami pernah pergi ke Betang Tumbang Malahoi (Betang Toyoi) yang lebih mudah dijangkau dibandingkan Betang Tumbang Anoi”

Nemiwaty (Guru Sejarah SMA Negeri

Tumbang Rungan) mengatakan,

"Meskipun sudah mengetahui cerita tentang Rapat Tumbang Anoi namun saya belum pernah pergi ke Betang Tumbang Anoi karena letaknya yang jauh. Dalam kegiatan lawatan sejarah, saya sering mengunjungi Betang Tumbang Malahoi yang lebih dekat (sekitar I,5 jam perjalanan darat). Kendalanya, karena tidak ada kendaraan sekolah, siswa dan guru berangkat menggunakan sepeda motor dan guru sering merasa cemas kalau terjadi masalah di sepanjang jalan.

Berdasarkan pengalaman langsung melakukan perjalanan ke Tumbang Anoi, akses perjalanan menuju lokasi situs bersejarah tersebut memang sangat terbatas. Akses perjalanan darat 
yang cukup baik hanya sampai di ibukota kecamatan, Tumbang Miri (kurang lebih I jam perjalanan darat dari Kota Kuala Kurun, ibukota Kabupaten Gunung Mas). Setelah itu, perjalanan dilanjutkan melalui jalan sempit dalam kondisi rusak untuk mencapai lokasi Betang Tumbang Anoi (kurang lebih 2 jam perjalanan darat). Pada musim hujan, setelah sampai di Desa Tumbang Miri, perjalanan ke Desa Tumbang Anoi dilanjutkan dengan naik perahu bermesin selama lebih kurang 3 jam.

\section{PEMBAHASAN}

Berdasarkan fakta yang ditemukan selama penelitian, materi sejarah lokal sangat penting dan meskipun tidak secara eksplisit ada dalam kurikulum $\mathrm{K}$ I3, namun dapat diberikan. Materi sejarah lokal tidak bertentangan dengan kurikulum $\mathrm{K}$ I3 bahkan menjadi bagian dari Kurikulum K I3. Sejarah lokal penting diajarkan agar generasi muda lebih mengenal identitasnya dan meningkatkan rasa kebangsaan melalui tokoh-tokoh lokal yang lebih membumi. Sebagai contoh, untuk Provinsi Kalimantan Tengah, sejarah perjuangan kemerdekaan Indonesia akan lebih mudah ditanamkan dengan mempelajari sejarah Tjilik Riwut, Pahlawan Nasional yang berasal dari
Provinsi Kalimantan Tengah. Tokoh lokal lebih mudah dikenali dan diikuti jejaknya. Penelitian ini sejalan dengan hasil penelitian Wijayanti (2017) bahwa penerapan sejarah lokal juga membawa perubahan positif pada diri siswa dengan mengenalkan sejarah lokal antara lain tumbuhnya nasionalisme, kesadaran sejarah, berpikir kritis, gotong royong, dan sebagainya.

Salah satu peristiwa bersejarah di Provinsi Kalimantan Tengah adalah pertemuan Tumbang Anoi yang diselenggaraakan pada tahunl894. Bertindak sebagai tuan rumah adalah Damang Batu serta melibatkan semua anak suku Dayak di seluruh Kalimantan yang selama berabad-abad saling berperang. Dampak terbesar pertemuan Tumbang Anoi adalah perdamaian. Setelah pertemuan Tumbang Anoi, hubungan antar anak suku Dayak berubah total, orang-orang sudah berani bepergian keluar betang bahkan pergi ke tempat-tempat jauh tanpa rasa takut. Pertemuan Tumbang Anoi juga membuktikan bahwa suku Dayak merupakan entitas yang mau belajar dan sudah belajar serta "mau berubah" untuk kelangsungan hidup anak cucunya. Kesadaran untuk merubah ini merupakan hasil proses belajar internal di kalangan suku Dayak. Dampak lain adalah perdagangan. Diantara delegasi yang hadir sebagian adalah 
pedagang, sehingga motif ekonomi (perdagangan) sangat jelas terbayang dalam pertemuan Tumbang Anoi tersebut.

Berdasarlan hasil wawancara, bahwa ada tiga materi penting yang disepakati dalam Pertemuan Tumbang Anoi, yaitu I) penghentian perang antar suku, ngayau dan balas dendam; 2) penghentian perbudakan dan pembebasan budak-budak; dan 3) penyeragaman hukum adat dalam tata kehidupan suku dayak, yaitu dalam acara kematian dan perkawinan. Kebiasaan pembayaran dengan budak (jipen) pada upacara perkawinan dan kematian diganti dengan uang atau benda-benda berharga (emas, guci, piring, mangkok). Temuantemuan ini mengkonfirmasi hasil penelitian sebelumya (Rusan, 2002; Siregar, 2003). Siregar (2003) menyatakan bahwa setelah Perteamuan Tumbang Anoi, suku Dayak mulai membuka lahan jauh dari rumah betangnya untuk mencari lahan yang subur.

Situs Betang Tumbang Anoi sebagai tempat penyelenggaraan pertemuan yang bersejarah tersebut dapat menjadi sumber pembelajaran sejarah. $\mathrm{Hal}$ ini terlihat dari foto-foto dokumentasi yang berada di dinding bangunan (gambar I). Foto dokumentasi yang terdapat di dinding bangunan menunjukkan beberapa snopshoot (potongan peristiwa) pertemuan Tumbang
Anoi yang diambil dari arsip Pemerintah Belanda. Di samping doto dokumentasi, juga terdapat lukisan tentang kemeriahan pertemuan Tumbang Anoi. Keberadaan sebuah situs sebagai sumber pembelajaran sejarah lokal juga diteliti oleh Guntur dkk. (2018) di Kraton Bhuton, yang menyimpulkan bahwa Kraton Buton sebagai bekas pusat pemerintahan Kesultanan Buton dan sebagai pusat kebudayaan Buton menyimpan peninggalanpeningalan yang unik dan menarik. Para Pengelola Betang Tumbang Anoi - seperti halnya Pengelola Kraton Bhutan - membuka diri bagi bagi para guru dan siswa untuk memanfaatkan Betang Tumbang Anoi sebagai tempat belajar dan melaksanakan penelitian.

Pembelajaran sejarah lokal dengan melihat situs sejarah secara langsung dianggap memberikan efek positif yang lebih besar. Siswa bisa berinetarksi langsung dengan tempat dan benda bersejarah dan kemudian diekpresikan ke media social. Siswa kemudian memberikan komentar (caption) yang berkaitan dengan tempat dan benda bersejarah tersebut serta memberikan penjelasan yang diperlukan. Metode ini membuat siswa cepat paham dan lebih mudah mengingat peristiwa bersejarah. Belajar dengan melihat langsung tempat dan benda bersejarah merupakan proses belajar 
yang melibatkan ranah-ranah kognitif, afektif dan ranah psikomotorik. Proses belajar yang mengaktualisasikan ketiga ranah tersebut akan lebih mudah dipahami siswa. Hal ini sejalan dengan penelitian terdahulu yang dilakukan oleh Nidawati (2013).

Dalam konteks Betang Tumbang Anoi sebagai sumber pembelajaran sejarah lokal mengalami hambatan karena letak geografis yang jauh. Meskipun segala sarana dan prasarana di Betang Tumbang Anoi sangat memadai jika digunakan sebagai sumber pembelajaran sejarah lokal, namun relatif jarang dikunjungi siswa. Pengunjung Betang Tumbang Anoi adalah para wisatawan baik dari dalam maupun luar negeri. Hal ini disebabkan biaya perjalanan yang relatif mahal untuk ukuran masyarakat lokal. Perjalanan dari Kota Palangka Raya (ibukota Provinsi Kalimantan Tengah) memakan waktu 10 jam, dengan sebagian medan sulit untuk dilalui. Pada musim hujan, jalan darat tidak bisa dilalui dan harus dilakkan dengan kendaraan air (kelotok) selama $2-3$ jam. Biaya perjalanan dari Kota Palangka Raya ke Betang Tumbang Anoi sekitar Rp. I.000.000 per orang.

Kendati susah dikunjungi, Betang Tumbang Anoi dan pertemuan Damai Tumbang Anoi tetap menjadi sumber pembelajaran sejarah lokal yang sangat penting. Semua guru sejarah mengajarkannya di kelas. Guru-guru sejarah di Kota Palangka Raya dan Kabupaten Gunung Mas menggunakan gambar dan foto yang diperoleh dari internet sebagai alat bantu belajar. Gambar dan foto tentang Betang Tumbang Anoi dan Pertemuan Damai Tumbang Anoi tersebut pada hakeketnya berfungsi seagai alat bantu atau alat peraga untuk melibatkan ranahranah kognitif, afektif dan ranah psikomotorik siswa yang memiliki fungsi dan keguanaan mirip dengan benda aslinya. Seperti halnya penelitiaan-penelitian sebelumnya di bidang sejarah (Nandia, 2016), pendidikan Agama Islam (Maesaroh, 2013), Matematika (Suwardi, 20I4; Khotimah dan Risang, 2019) dan Biologi (Saleh dkk., 20l5), bahwa penggunaan alat peraga mampu meningkatkan tingkat pemahaman siswa terhadap satu topik tertentu dari mata pelajaran tertentu.

Temuan-temuan dalam penelitian ini menkonfirmasi hasil penelitian sebelumnya yang dilakukan oleh Wijayanti (2017) tentang pentingnya pembelajaran sejarah lokal dal penelitian Guntur dkk. (2018) tentang peranan sebuah situs lokal sebagai sumber pembelajaran sejarah lokal.

\section{KESIMPULAN}


Kesimpulan penelitian ini adalah sebagai berikut :

I. Materi sejarah lokal sangat penting dan meskipun tidak secara eksplisit ada dalam kurikulum $\mathrm{K}$ 13, namun dapat diberikan. Materi sejarah lokal tidak bertentangan dengan kurikulum $\mathrm{K}$ I3 bahkan menjadi bagian dari Kurikulum $\mathrm{K}$ 13. Sejarah lokal penting diajarkan agar generasi muda lebih mengenal identitasnya dan meningkatkan rasa kebangsaan melalui tokoh-tokoh lokal yang lebih membumi. Pembelajaran sejarah lokal juga membawa perubahan positif pada diri siswa dengan mengenalkan sejarah lokal antara lain tumbuhnya nasionalisme dan kesadaran sejarah.

2. Betang Tumbang Anoi sebagai tempat pertemuan damai Tumbang Anoi dapat dijadikan sebagai sumber pembelajaran sejarah lokal Provinsi Kalimantan Tengah, namun pemanfaatannya secara langsung menghadapi kendala berupa letak geografis yang jauh, prasarana transportasi yang berat dan biaya perjalanan yang mahal.

3. Pemanfaatan Betang Tumbang Anoi sebagai sumber pembelajaran sejarah lokal menggunakan alat bantu berupa gambar atau foto yang diperoleh melalui internet yang terbukti mampu meningkatkan tingkat pemahaman siswa.

\section{UCAPAN TERIMA KASIH}

Para penulis menyampaikan terima kasih kepada Kemenntrian Riset Teknologi dan Pendidikan Tinggi Republik Indonesia yang telah memfasilitasi penelitian ini. Ucapan penghargaan dan terima kasih juga kami haturkan kepada Gauri Rampai yang memberikan banyak ide dan masukan terhadap gagasan awal penelitian yang dilakukan penulis.

\section{DAFTAR PUSTAKA}

Khotimah,S.H. dan Risang. 2019. "Pengaruh Penggunaan Alat Peraga Terhadap Hasil Belajar Matematika Pada Materi Bangun Ruang." Jurnal Penelitian dan Pengembangan Pendidikan. 3 (I) : 4855.

Maesaroh, S. 2013. "Peranan Metode Pembelajaran terhadap Minat dan Prestasi Belajar Pendidikan Agama Islam." Jurnal Kependidikan, I (I) : 150 168

Nandia, A., H. J. Waluyo dan S. Haryanto. 2016. "Pengembangan Media Pembelajaran Sejarah Berbasis Media Audio Visual Situs Purbakala Pugung Raharjo untuk Meningkatkan Kesadaran Sejarah Siswa Kelas X SMA Negeri I Kotagajah." Jurnal Ilmiah Dikdaya. 3 (I) : 29 - 45

Nidawati. 20I3. "Belajar dalam Persfektif Psikologi dan Agama." Jurnal Pionir, I (I) $: 13-28$ 
Nazir, Muhammad. 2003. Metode Penelitian.

Menengah Atas" Jurnal Artefak: History and Ghalia Indonesia. Jakarta

Rusan, A.S. 2002. Sejarah Kalimantan Tengah. Propinsi Kalimantan Tengah. Palangka Raya.

Saleh, H.I. Nurhayati B dan O. Jumadi. 2015. "Pengaruh Penggunaan Media Alat Peraga Terhadap Hasil Belajar Siswa pada Materi Sistem Peredaran Darah Kelas VIII SMP Negeri 2 Bulukumba." Jurnal Sainsmat, IV (I\} : 713

Sayono, Joko. 2017. "Pembelajaran Sejarah di Sekolah : Dari Pragmatis ke Idealis" Sejarah dan Budaya. 7 (I) : 9 - 17.

Siregar, B.B. 2003. "Modal Sosial Komunitas Perladangan (Kasus Komunitas Kanarakan, Kecamatan Bukit Batu Kota Palangka Raya, Kalimantan Tengah).” Tesis. Sekolah Pasca Sarjana. IPB. Bogor.

Sirnayatin, 2017. "Membangun Karakter Bangsa melalui Pembelajaran Sejarah" Jurnal SAP. I (3) : 312-32I.

Suwardi, M.E. Firmiana dan Rohayati. 2014. "Pengaruh Penggunaan Alat Peraga terhadap Hasil Pembelajaran Matematika pada Anak Usia Dini." Jurnal Al Azhar Indonesia Seri Humaniora $2(4): 297-305$

Suwarno. 2017. "Budaya Huma Betang Masyarakat Dayak Kalimantan Tengah dalam Globalisasi : Telaah Konstruksi Sosial”. Lingua I4 (I) : 89 - 102.

Tukidi. 20II. Membangun Karakter Bangsa di Tengah-Tengah Budaya Global. Jurnal Forum Ilmu Sosial, I (38) : $44-54$.

Wijayanti, Y. 2017. "Peranan Penting Sejarah Lokal dalam Kurikulum di Sekolah 